\title{
Anoctamin5 regulates cell migration and invasion in thyroid cancer
}

\author{
ZHENGYAN CHANG $^{1}$, CHUNMIAO CAI $^{1}$, DONGYAN HAN ${ }^{1}$, YAOHUI GAO $^{1}$, QIANYU LI $^{1}$, LIJIN FENG $^{1}$, \\ WEI ZHANG ${ }^{1}$, JIAYI ZHENG ${ }^{1}$, JIAOYING JIN ${ }^{1}$, HUIZHEN ZHANG ${ }^{2}$ and QING WEI $^{1}$ \\ ${ }^{1}$ Department of Pathology, Shanghai Tenth People's Hospital, Tongji University, Shanghai 200072; \\ ${ }^{2}$ Department of Pathology, Shanghai Sixth People's Hospital, Shanghai Jiao Tong University, Shanghai 200233, P.R. China
}

Received June 9, 2017; Accepted August 25, 2017

DOI: 10.3892/ijo.2017.4113

\begin{abstract}
Anoctamin/TMEM16 family members have recently been identified as novel calcium-activated chloride channels, and dysregulation of many family members participates in tumorigenesis and progression. However, the exact role of anoctamin5 (ANO5), one member of this family, in thyroid cancer is still not clarified. In this study, we firstly found that the expression levels of ANO5 was significantly downregulated in thyroid cancer compared to adjacent normal tissue by mining the public GEO database. Subsequently, we further demonstrated that the expression levels of ANO5 was significantly downregulated in $69.5 \%$ (57/82) clinical thyroid cancer tissues using real-time PCR assay. Moreover, western blot assay also showed that ANO5 was downregulated in papillary thyroid cancer and follicular thyroid cancer compared to adjacent noncancerous tissues. Furthermore, some biological and functional in vitro experiments proved that ANO5 knockdown promotes thyroid cancer cell migration and invasion but overexpression of $A N O 5$ inhibits these phenotypes. By analyzing gene set enrichment, we found that lower ANO5 expression was positively associated with JAK/STAT3 signaling pathway. Collectively downregulation of $A N O 5$ promotes thyroid cancer cell migration and invasion by affecting $J A K /$ STAT3 pathway.
\end{abstract}

\section{Introduction}

Papillary thyroid cancer (PTC) and follicular thyroid cancer (FTC) are the most common types of thyroid cancer, accounting for $94 \%$ of all cases (1). Most of them

Correspondence to: Professor Qing Wei, Department of Pathology, Shanghai Tenth People's Hospital, Tongji University, 301 Yanchang Road, Shanghai 200072, P.R. China

E-mail: weiqing1971@126.com

Professor Huizhen Zhang, Department of Pathology, Shanghai Sixth People's Hospital, Shanghai Jiao Tong University, 600 Yi Shan Road, Shanghai 200233, P.R. China

E-mail: liuyuanblz@aliyun.com

Key words: anoctamin5, thyroid cancer, migration, invasion are differentiated and have a good prognosis with a 10 -year survival rate of $>92 \%$ (2). But among clinical staging criteria, metastatic lymphadenopathy is one of the best predictors of a poor prognosis, recurrence and motility (3-5) as it likely reflects aggressive primary tumor biology $(6,7)$ (seer. cancer.gov/statfacts/html/oralcav.html). So exploring the mechanism of lymph node metastasis will deepen our understanding of malignant characteristics of some differentiated thyroid cancer.

Anoctamin family ( $A N O$, also known as TMEM16) contains 10 members which are identified as putative intracellular calcium activated chloride channels $(8,9)$. It has been reported that some members of anoctamin family are overexpressed in cancer (10), moreover, overexpression of ANO1 and ANO6 can increase cancer cell migration $(11,12)$. Anoctamin5 (ANO5), also referred to as TMEM16E, is one member of the anoctamin family. Somatic mutation or microdeletion of $A N O 5$ usually results in muscular dystrophy (13-18), but its exact role in tumorigenesis and cancer progression is still not clear.

We first evaluated the expression profile of this family in thyroid cancer by mining the public GEO database. We discovered and proved the downregulation of ANO5 expression in thyroid cancer. Thereafter, we revealed that downregulation of ANO5 is negatively associated with lymph node metastasis and inhibition of $A N O 5$ promotes the migration and invasion of thyroid cancer cells. In addition, we also found that lower ANO5 expression was positively associated with JAK/STAT3 pathway which is well-known to be activated during cancer metastasis $(19,20)$. The present results provided novel insight into $A N O 5$ 's function in thyroid cancer metastasis.

\section{Materials and methods}

Tissue specimens and cell lines. Thyroid cancer tissue samples used in this study were harvested from Shanghai Tenth People's Hospital between November, 2013 and December, 2015. Written informed consent from all patients was obtained. Thyroid cancer cell lines TPC-1 and FTC-133 were obtained by Dr Lei Ye in Rui-Jin Hospital. TPC-1 cells were maintained in RPMI-1640 medium and FTC-133 cells were cultured in Dulbecco's modified Eagle's medium (DMEM) supplemented 
with $10 \%$ fetal bovine serum (FBS) (both from HyClone, Logan, UT, USA) $100 \mathrm{U} / \mathrm{ml}$ penicillin, and $100 \mu \mathrm{g} / \mathrm{ml}$ streptomycin.

Antibodies and reagents. The target antibodies were purchased from Abcam.

RNA extraction and real-time PCR. Total RNA was extracted with TRIzol ${ }^{\circledR}$ (Invitrogen, Garlsbad, CA, USA), following the manufacturer's protocol. The OD260/OD280 ratio of RNA ranged from 1.8 to 2.0. Reverse transcription was performed in $20 \mu 1$ reaction volume with $2 \mu \mathrm{g}$ of RNA using M-MLV reverse transcriptase kit (Takara, Otsu, Japan). Quantitative real-time PCR was carried out using ABI 7900 Detection system with the SYBR Premix Ex Taq ${ }^{\mathrm{TM}}$ (Takara). Primer sequences specific to 38 genes and housekeeping gene GADPH are listed in Table I.

Protein extraction and western blot analysis. Total cellular proteins were extracted using cell lysis buffer containing $50 \mathrm{mM}$ Tris- $\mathrm{HCl}$ (pH 6.8), 2\% SDS, $10 \%$ glycerol, $10 \%$ 2-mercaptoethanol, and protease inhibitor cocktail (Sigma, St. Louis, MO, USA). Then protein concentration was determined using the BCA kit (Thermo Fisher Scientific, Waltham, MA, USA). Protein $(30 \mu \mathrm{g})$ was subjected to electrophoresis by SDS-PAGE on the $10 \%$ gel and then transferred to a polyvinylidene difluoride (PVDF) membrane. The membrane was blocked with $5 \%$ bovine serum albumin (BSA) and $0.1 \%$ Tween-20 in PBS for $2 \mathrm{~h}$ at room temperature. After incubation with the appropriate primary antibody overnight at $4^{\circ} \mathrm{C}$ with anti-ANO5 (1:500), anti-STAT3 $(1: 1,000)$, anti-p727-STAT3 (1:1,000) (all from Abcam), and anti-GAPDH (1:3,000; Santa Cruz Biotechnology, Inc., Santa Cruz, CA, USA) antibodies, membranes were washed and incubated with the IRDye $800 \mathrm{CW}$ secondary antibodies for $1 \mathrm{~h}$ at room temperature. The labeled protein bands were detected using the Odyssey Infrared Imaging system (Li-COR Biosciences, Lincoln, NE, USA). GADPH was used as a loading control.

Construction of ANO5 expression vectors. Human full-length ANO5 cDNA (GenBank accession no. NM_001142649.1) was acquired from normal thyroid tissues. Primers for PCR amplification were designed as follows: forward, 5'-ATA TCT AGA ATG GGC GAC CCG GAT CTC CTG GAA G-3' and reverse, 5'-ACG CGG CCG CTT AGA GTG TTG ATT TAG CCA GCT G-3'. The PCR product was subcloned into the pCDH vector (Systembioscience, Inc.) and verified by restriction digestion and DNA sequencing.

Lentivirus production. All recombinant lentiviruses were produced by transfecting HEK293T cells according to standard protocols. In brief, sub-confluent HEK293T cells were co-transfected with $4 \mu \mathrm{g} \mathrm{pCDH}-A N O 5$ plasmid vector, $3 \mu \mathrm{g}$ PLP1, $3 \mu \mathrm{g}$ PLP2 and $2 \mu \mathrm{g}$ PLP-VSVG in $50 \mu 1$ Lipofectamine 2000. The medium was changed after $16 \mathrm{~h}$ and supernatant was harvested $72 \mathrm{~h}$ later.

siRNA synthesis. One siRNA against ANO5 was chemically synthesized and the sequences were listed as follows: siRNA-1269, 5'-GCU GUA GUU GGC UUA GCU UTT-3';
siRNA-2487, 5'-GCU CAU AGC AUA GGU GUU UTT-3'. The non-targeting nucleotides were used as a negative control siRNA-NC, 5'-UUC UCC GAA CGU GUC ACG UTT-3'.

In vitro migration and invasion assays. Cell migration/invasion assays were performed using 24-well Transwells $(6.5 \mathrm{~mm}$ pore size, Costar), coated without (migration) or with (invasion) Matrigel. TPC-1 and FTC-133 cells were starved in serumfree media for $12 \mathrm{~h}$, trypsinized and washed three times in RPMI-1640/DMEM containing 0.1\% BSA. Cells $\left(1 \times 10^{4}\right)$ were seeded into the upper chamber, and $600 \mu \mathrm{l}$ medium containing $10 \% \mathrm{FBS}$ was placed in the lower chamber at $37^{\circ} \mathrm{C}$ in $5 \% \mathrm{CO}_{2}$. After $48 \mathrm{~h}$ incubation, Matrigel and cells remaining in the upper chamber were removed. Cells on the lower surface of the membrane were fixed in $4 \%$ paraformaldehyde and stained with Coomassie Brilliant Blue, photographed and counted under a dissecting microscope. Every experiment was repeated three times.

Gene set enrichment analysis (GSEA). GSEA was carried out using GSEA software according to literature $(21,22)$. Firstly we classified thyroid cancer samples (GSE3678) into ANO5 high expression and $A N O 5$ low expression group according to ANO5 expression, subsequently three gene sets including KEGG, Hallmark and BioCarta were chosen to conduct GSEA.

Statistical analysis. The statistical difference of quantitative variables was evaluated with Student's t-test using GraphPad Prism 5 software and R x64 3.2.2 software, p $<0.05$ was considered statistically significant.

\section{Results}

ANO5 is downregulated in thyroid cancer. In order to find differentially expressed genes in thyroid cancer and adjacent normal tissue, a GEO dataset (GSE3678) which contains seven cancerous and seven normal tissues was chosen. A total of 38 genes were discovered to display at least 3-fold alterations (Fig. 1A). Furthermore, we evaluated expression of these 38 genes in clinical thyroid cancer tissues and adjacent noncancerous tissues by real-time PCR (Fig. 1B). We found that the expression of some genes including TPO (23), ANO5, ERBB4 (24) and SLC4A4 (25) genes were in accordance with the results of GEO gene expression atlas (Fig. 1A), then we focused on ANO5 and its family through biological information analysis and previous literature studies. In order to investigate the role of anoctamin family in thyroid cancer progression, we first measured the expression profile of this family in thyroid cancer tissue samples by mining a public database (GSE3678). Interestingly, only ANO5 was significantly downregulated in thyroid cancer compared to adjacent noncancerous tissues (Fig. 1C). Subsequently we confirmed that $69.5 \%$ (57/82) thyroid cancer showed up to 2 -fold downregulation of ANO5 by real-time PCR assay (Fig. 1D). Similarly, western blot assay also proved that ANO5 is downregulated in PTC and follicular thyroid cancer compared to adjacent noncancerous tissues (Fig. 1E). Collectively, these data revealed that ANO5 expression is significantly downregulated in thyroid cancer. 
Table I. Real-time PCR primers utilized in this study.

\begin{tabular}{|c|c|}
\hline Genes & Sequences \\
\hline ADH1B & $\begin{array}{l}\text { F: CCCGGAGAGCAACTACTGC } \\
\text { R: AACCAGTCGAGAATCCACAGC }\end{array}$ \\
\hline ANO5 & $\begin{array}{l}\text { F: TTTTGGAAACAACGACAAGCCA } \\
\text { R: ACCATACTGGTGACGACAAGAG }\end{array}$ \\
\hline BMP2 & $\begin{array}{l}\text { F: ACCCGCTGTCTTCTAGCGT } \\
\text { R: TTTCAGGCCGAACATGCTGAG }\end{array}$ \\
\hline CDH16 & $\begin{array}{l}\text { F: GTCCCTAGAGCCTATCCACCT } \\
\text { R: TGCATTCACTTCAAAGGGTCC }\end{array}$ \\
\hline CLCNKB & $\begin{array}{l}\text { F: GCCCTCCTTCTATGATGGCAC } \\
\text { R: CCTGCCCTTGGTGACAGTG }\end{array}$ \\
\hline DLG2 & $\begin{array}{l}\text { F: CCTCTACGTCAGAGCCATGTT } \\
\text { R: ATCGGGCACGTTCCTTTCTTT }\end{array}$ \\
\hline DPP6 & $\begin{array}{l}\text { F: CTACGCCGCCATCAATGATTC } \\
\text { R: GGGATAGTGGTAGGGCTTCAC }\end{array}$ \\
\hline DPY19L2 & $\begin{array}{l}\text { F: CTTCCAGTTCGTCCGTAATTCC } \\
\text { R: TCTCCCGTTCCAAAGATGAGAG }\end{array}$ \\
\hline EDN3 & $\begin{array}{l}\text { F: GGGACTGTGAAGAGACTGTGG } \\
\text { R: AGACACACTCCTTGTCCTTGTA }\end{array}$ \\
\hline ERBB4 & $\begin{array}{l}\text { F: GTCCAGCCCAGCGATTCTC } \\
\text { R: AGAGCCACTAACACGTAGCCT }\end{array}$ \\
\hline ESRRG & $\begin{array}{l}\text { F: GCCCTCACTACACTGTGTGAC } \\
\text { R: CCTGCTAATTTGGACTGGTCTT }\end{array}$ \\
\hline FABP4 & $\begin{array}{l}\text { F: ACTGGGCCAGGAATTTGACG } \\
\text { R: CTCGTGGAAGTGACGCCTT }\end{array}$ \\
\hline FHL1 & $\begin{array}{l}\text { F: AAGAACCGCTTCTGGCATGAC } \\
\text { R: CCCCTTGTACTCCACGTTTTG }\end{array}$ \\
\hline FOS & $\begin{array}{l}\text { F: CCGGGGATAGCCTCTCTTACT } \\
\text { R: CCAGGTCCGTGCAGAAGTC }\end{array}$ \\
\hline GHR & $\begin{array}{l}\text { F: CCATTGCCCTCAACTGGACTT } \\
\text { R: AATATCTGCATTGCGTGGTGC }\end{array}$ \\
\hline GNA14 & $\begin{array}{l}\text { F: GAGCGATGGACACGCTAAGG } \\
\text { R: TCCTGTCGTAACACTCCTGGA }\end{array}$ \\
\hline GPM6A & $\begin{array}{l}\text { F: ATTCCСТATGCCTCTCTGATTGC } \\
\text { R: GCCATCTCAAAGTAGGTTTGCAG }\end{array}$ \\
\hline HGD & $\begin{array}{l}\text { F: ATTTACACCGAGTTTGGCAAGA } \\
\text { R: GGTCTCCTCAAAGACATCTATGC }\end{array}$ \\
\hline ITPR1 & $\begin{array}{l}\text { F: ATTGCTGGGGACCGTAATCC } \\
\text { R: TCCAATGTGACTCTCATGGCA }\end{array}$ \\
\hline KIAA1324 & $\begin{array}{l}\text { F: GGAGCTTCATGCCTGCAAAGA } \\
\text { R: CATCAAACCGAATGCCTGTGC }\end{array}$ \\
\hline LIFR & $\begin{array}{l}\text { F: TGGAACGACAGGGGTTCAGT } \\
\text { R: GAGTTGTGTTGTGGGTCACTAA }\end{array}$ \\
\hline LRP2 & $\begin{array}{l}\text { F: GTTCAGATGACGCGGATGAAA } \\
\text { R: TCACAGTCTTGATCTTGGTCACA }\end{array}$ \\
\hline PID1 & $\begin{array}{l}\text { F: CGTGGAGTGCGAGAGCAAG } \\
\text { R: CTGGGAAACCTCTTCGGAGGA }\end{array}$ \\
\hline PLA2R1 & $\begin{array}{l}\text { F: TAAATCGGTTCTGACCCTGGA } \\
\text { R: GCCACCGTAAGGAAACGAG }\end{array}$ \\
\hline PTHLH & $\begin{array}{l}\text { F: AAGGTGGAGACGTACAAAGAGC } \\
\text { R: CAGAGCGAGTTCGCCGTTT }\end{array}$ \\
\hline
\end{tabular}

Table I. Continued.

\begin{tabular}{|c|c|}
\hline Genes & Sequences \\
\hline RYR2 & $\begin{array}{l}\text { F: CATCGAACACTCCTCTACGGA } \\
\text { R: GGACACGCTAACTAAGATGAGGT }\end{array}$ \\
\hline SLC26A4 & $\begin{array}{l}\text { F: TGGTGGGATCTGTTGTTCTGA } \\
\text { R: GGATCTGCCAAGTACCTCACT }\end{array}$ \\
\hline SLC26A7 & $\begin{array}{l}\text { F: GTGACCCAAGGATTGGCCTTT } \\
\text { R: GGCAACATGATGTCCCATTCC }\end{array}$ \\
\hline SLC4A4 & $\begin{array}{l}\text { F: GGGTGCCCTGACTGAAGTTC } \\
\text { R: GGTCGTGCCTGTCTTTTGCT }\end{array}$ \\
\hline TFF3 & $\begin{array}{l}\text { F: CCAAGCAAACAATCCAGAGCA } \\
\text { R: GCTCAGGACTCGCTTCATGG }\end{array}$ \\
\hline TMEM171 & $\begin{array}{l}\text { F: AACCGCTAAACGAGACAGACA } \\
\text { R: ACACAATCCCACAAGCACAATC }\end{array}$ \\
\hline TMPRSS3 & $\begin{array}{l}\text { F: TGGAAGGGTCACTACGCAAAT } \\
\text { R: AGTGGTGTAATGCAGTCACCT }\end{array}$ \\
\hline TNFRSF11B & $\begin{array}{l}\text { F: GCGCTCGTGTTTCTGGACA } \\
\text { R: AGTATAGACACTCGTCACTGGTG }\end{array}$ \\
\hline TPO & $\begin{array}{l}\text { F: GCCAACAAGCGGAGTGATTG } \\
\text { R: GGGCAGCATGTAAGGGAGAC }\end{array}$ \\
\hline ТPPP & $\begin{array}{l}\text { F: AGGGGTGACGAAAGCCATC } \\
\text { R: CGGACACATAGCCTGACTCG }\end{array}$ \\
\hline WSCD2 & $\begin{array}{l}\text { F: AAACCTGTGCGCTTCTTTACC } \\
\text { R: GTACCTGCGAGCAATGCTTGA }\end{array}$ \\
\hline KLK7 & $\begin{array}{l}\text { F: TAATGACCTCATGCTCGTGAAGC } \\
\text { R: CAGCCGGAGACAGTACAGG }\end{array}$ \\
\hline GAPDH & $\begin{array}{l}\text { F: CTGGGCTACACTGAGCACC } \\
\text { R: AAGTGGTCGTTGAGGGCAATG }\end{array}$ \\
\hline
\end{tabular}

F, forward; R, reverse.

Downregulation of ANO5 is positively associated with lymph node metastasis of thyroid cancer. In order to explore the correlationship between downregulation of ANO5 and clinical characteristics, we analyzed RNA-seq data of thyroid cancer from TCGA database. We found that ANO5 expression is significantly associated with lymph node stage (N0 or N1, $\mathrm{p}=0.01$ ) and neoplasm histologic type (follicular or classical/papillary, $\mathrm{p}=6.97 \mathrm{E}-05$ ) (Table II), ANO5 expression levels in thyroid cancer with lymph node metastasis is lower than that without lymph node metastasis (Fig. 2A). Real-time PCR also confirmed the downregulation of ANO5 in thyroid cancer with lymph node metastasis compared to that without lymph node metastasis (Fig. 2B). In addition, we proved, as shown in Table III, ANO5 expression was significantly associated with lymph node metastasis (lymph node negative vs. lymph node positive, $\mathrm{p}=0.0038, \chi^{2}=8.376$ ) in our in-house samples. There are no significant association between ANO5 expression and other tumor characteristics, such as age, gender, size, Hashimoto background or multifocal disease (Table III). In order to carry out cellular and functional experiments, we next evaluated ANO5 expression in thyroid cancer cell lines, including FTC-133 and TPC-1, by real-time PCR, data show 

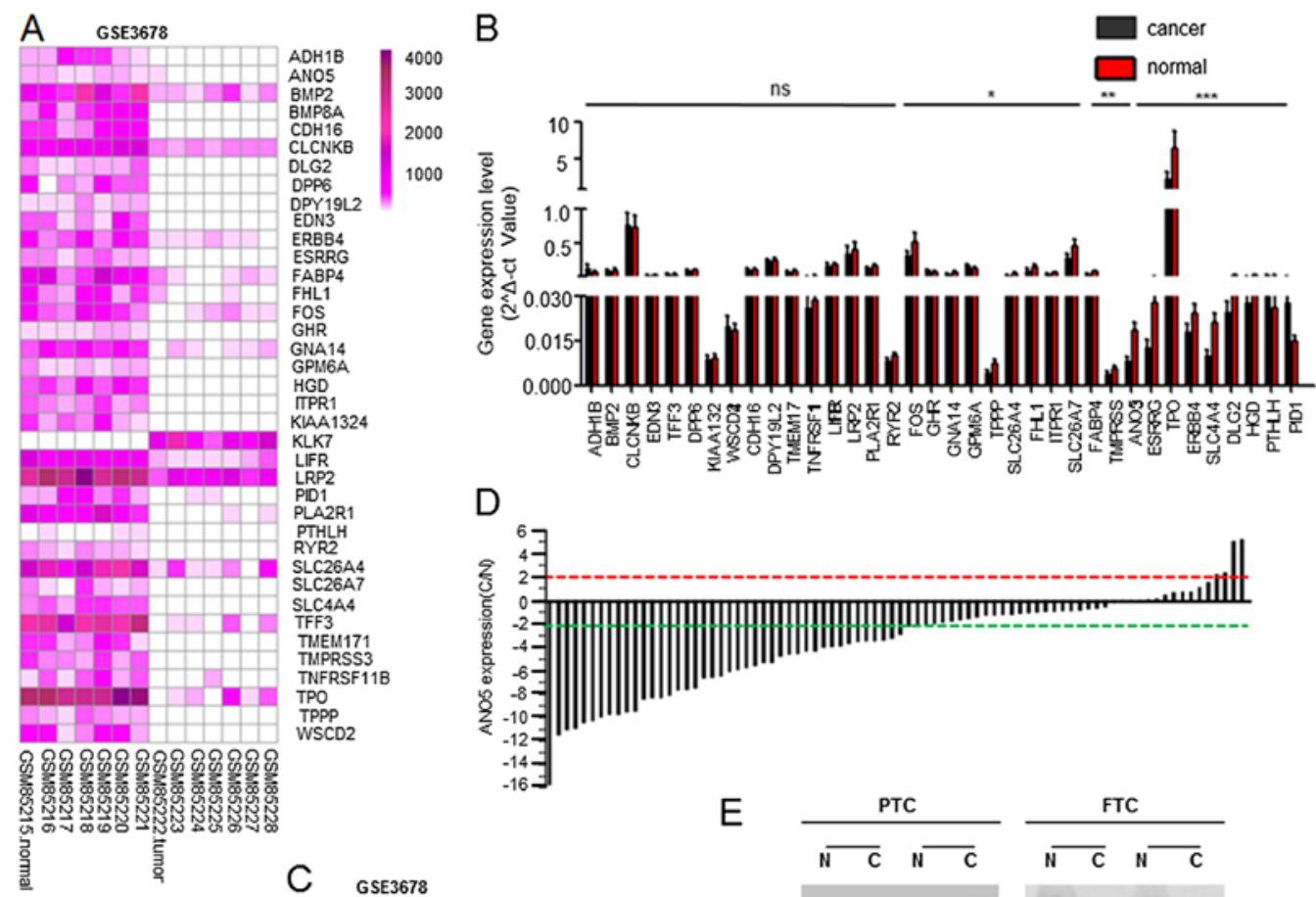

D
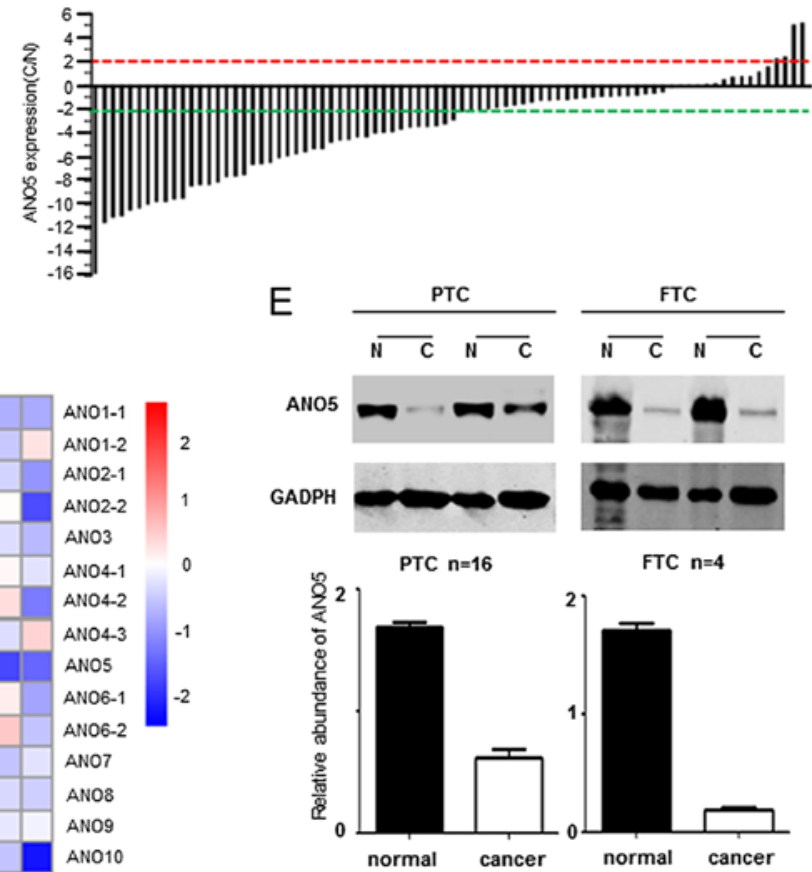

Figure 1. Anoctamin5 (ANO5) is downregulated in thyroid cancer. (A) Result of hierarchical clustering for top 38 differential expressed genes. (B) Real-time PCR assay validation of top 38 differential expressed genes in clinical thyroid cancer tissues. (C) The expression ratio of ANO family members in thyroid cancer and paired noncancerous tissue was calculated by mining public database (GSE3637). Negative value indicates gene expression is downregulated in thyroid cancer. (D) Real-time PCR assay was utilized to evaluate the expression of ANO5 in 82 paired thyroid cancer tissues. C, indicates thyroid cancer samples; N, represents paired noncancerous tissues. Green and red lines separately mean that gene expression is downregulated or upregulated twofold in thyroid cancer. (E) Western blotting was used to detect ANO5 expression in 16 paired papillary thyroid cancer (PTC) and 4 paired follicular thyroid cancer (FTC). " $\mathrm{p}<0.05 .{ }^{* *} \mathrm{p}<0.01$ and ${ }^{* * *} \mathrm{p}<0.001$. ns, no significant difference.

A

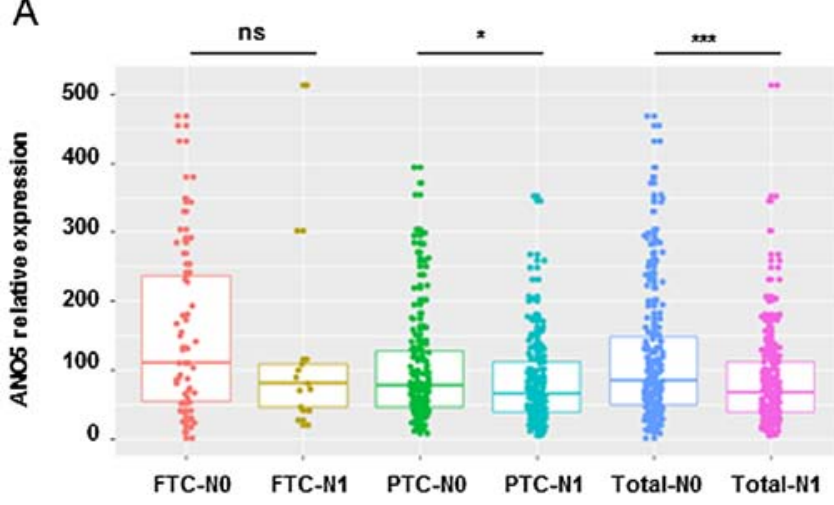

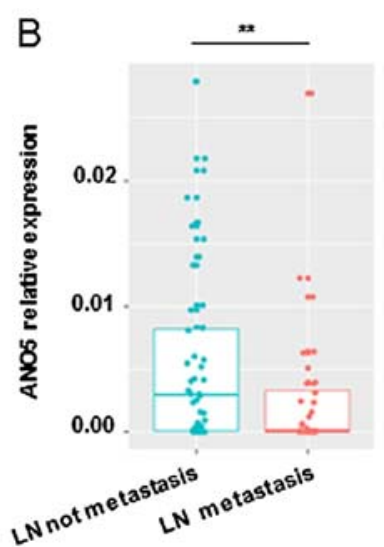

Figure 2. Downregulation of anoctamin5 (ANO5) is positively associated with lymph node metastasis. (A) TCGA data were used to compare ANO5 expression in thyroid cancer with or without lymph node metastasis (56 samples FTC-N0, 12 samples FTC-N1, 133 samples papillary thyroid cancer (PTC)-N0 and 161 samples PTC-N1). N0 indicates no lymph node metastasis, N1 represents lymph node metastasis. (B) Real-time PCR assay was utilized to measure ANO5 expression in 36 thyroid cancers with lymph node metastasis and 46 thyroid cancers without lymph node metastasis. ${ }^{*} \mathrm{p}<0.05$. ${ }^{* *} \mathrm{p}<0.01$ and ${ }^{* * *} \mathrm{p}<0.001$. ns, no significant difference. 
A
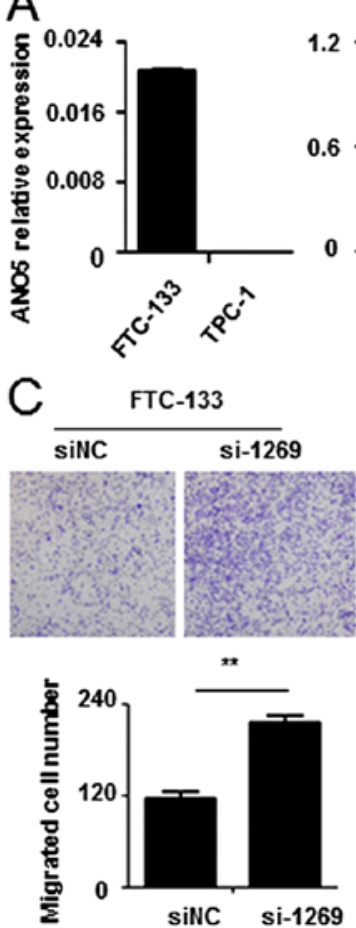
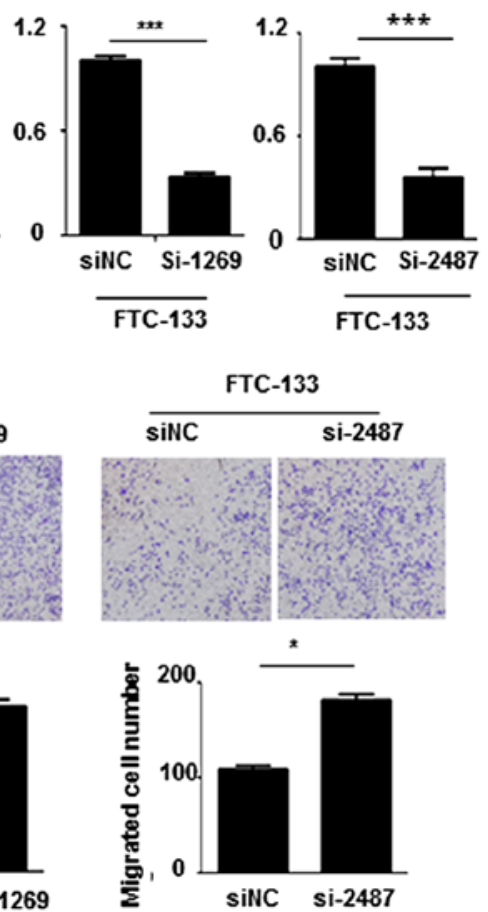

B
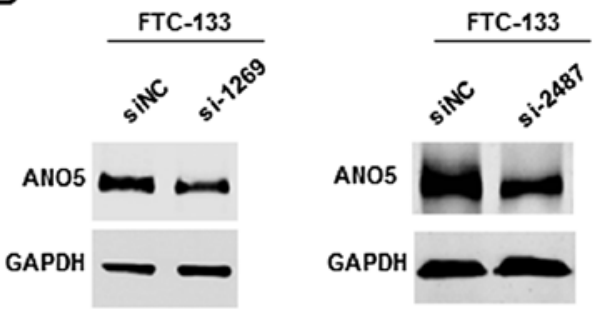

D
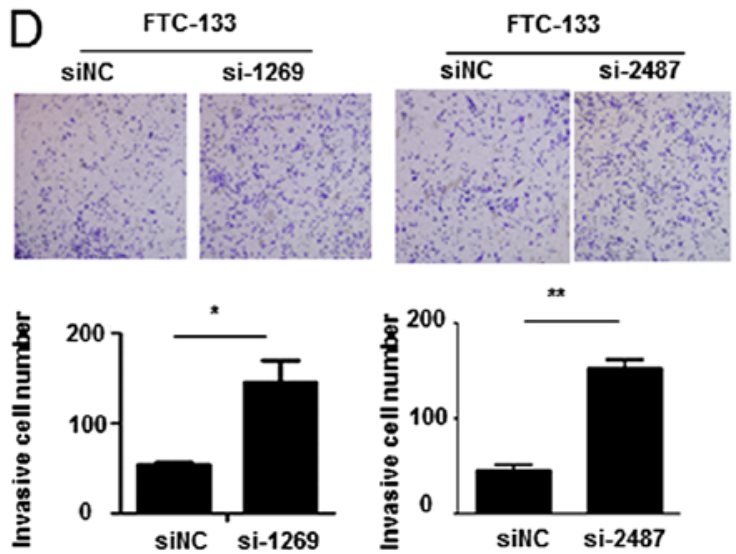

Figure 3. Knockdown of anoctamin5 (ANO5) promotes FTC-133 cell migration and invasion. (A) Real-time PCR was used to detect ANO5 expression in thyroid cancer cell lines. FTC-133 cells were transfected with siRNA against ANO5 (siANO5), and siNC served as negative control. After 48 h, RNA was extracted and ANO5 expression was evaluated with (A) real-time PCR and (B) western blotting. Transwell chambers coated without or with Matrigel were used to detect (C) migration or (D) invasion of FTC-133 cells (up). The number of cells was counted and compared (bottom). ${ }^{*} \mathrm{p}<0.05$. ${ }^{* * *} \mathrm{p}<0.01$ and ${ }^{* * * *} \mathrm{p}<0.001$.
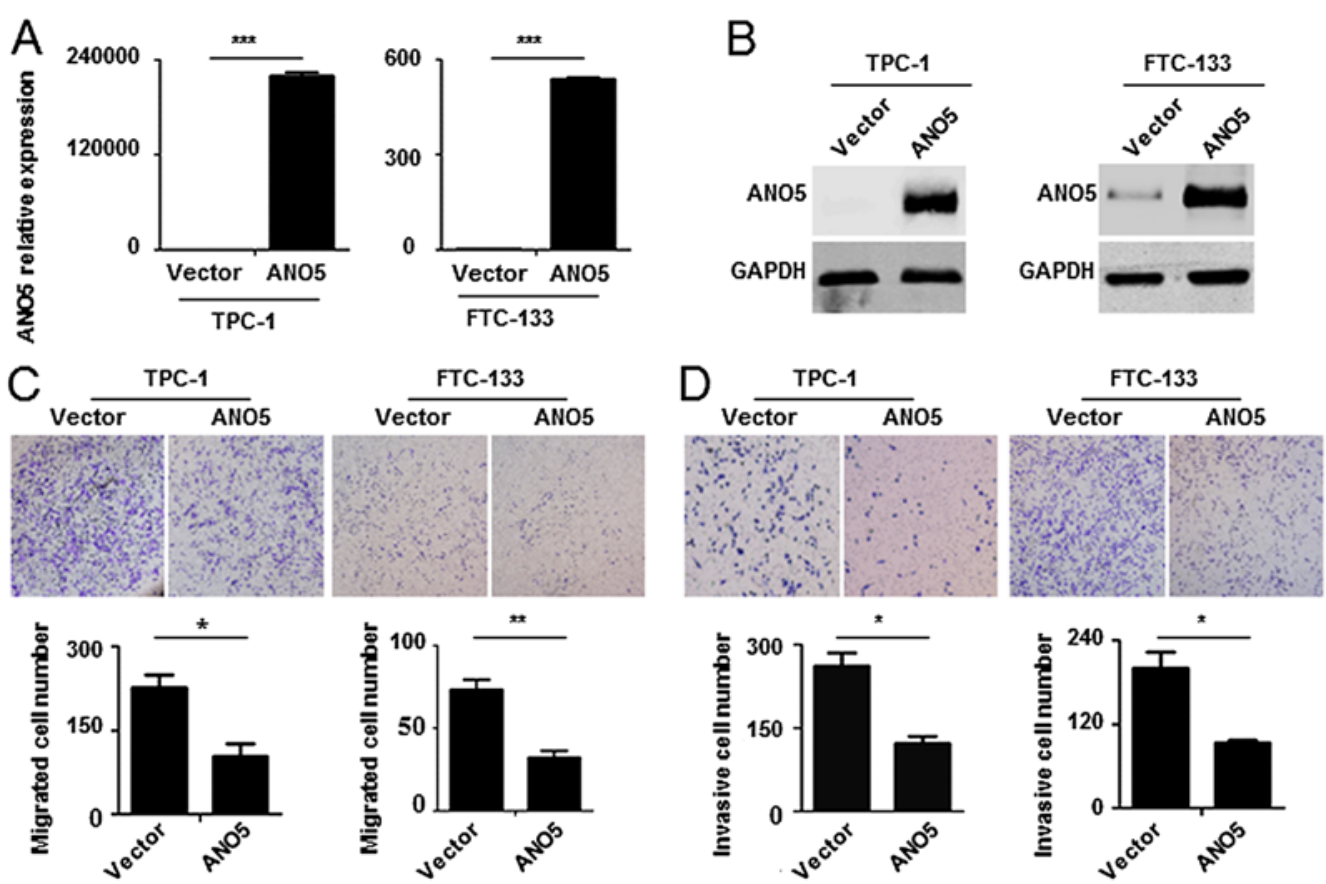

Figure 4. Overexpression of anoctamin5 (ANO5) inhibits FTC-133 and TPC-1 cells migration and invasion. TPC-1 and FTC-133 cells were infected with lentivirus expressing ANO5. After 72 h, RNA was collected, (A) real-time PCR and (B) western blot assays were used to measure ANO5 expression. Empty vector (vector) served as negative control. (C) Transwell assay was used to test the effect of ANO5 overexpression on FTC-133 and TPC-1 cell migration (up). Transferred cells were counted and compared (bottom). (D) Invasiveness of FTC-133 and TPC-1 cells was measured in Transwell chambers coated with Matrigel (up), and cells were counted and compared (bottom). ${ }^{*} \mathrm{p}<0.05$. ${ }^{* *} \mathrm{p}<0.01$ and ${ }^{* * *} \mathrm{p}<0.001$.

that ANO5 is undetectable in PTC cell line (Fig. 3A). In total, these findings indicate that downregulation of ANO5 is positively associated with lymph node metastasis of thyroid cancer.
Knockdown of ANO5 promotes FTC-133 cell migration and invasion. To understand whether ANO5 knockdown affects thyroid cancer cells migration and invasion, we 
Table II. The correlation of ANO5 expression with clinical characteristics of thyroid cancer from TCGA.

\begin{tabular}{|c|c|c|c|c|}
\hline \multirow[b]{2}{*}{ Clinical characteristic } & \multirow{2}{*}{$\begin{array}{l}\text { No. of } \\
\text { patients }\end{array}$} & \multicolumn{2}{|c|}{ ANO5 } & \multirow[b]{2}{*}{ p-value } \\
\hline & & High & Low & \\
\hline \multicolumn{5}{|l|}{ Age (years) } \\
\hline$\geq 60$ & 117 & 65 & 52 & \\
\hline$<60$ & 379 & 183 & 196 & 0.169 \\
\hline \multicolumn{5}{|l|}{ Gender } \\
\hline Male & 134 & 62 & 72 & \\
\hline Female & 362 & 186 & 176 & 0.312 \\
\hline \multicolumn{5}{|l|}{ Recurrence } \\
\hline Yes & 46 & 22 & 24 & \\
\hline No & 436 & 215 & 221 & 0.848 \\
\hline \multicolumn{5}{|c|}{ Overall survival (month) } \\
\hline$\geq 60$ & 97 & 41 & 56 & \\
\hline$<60$ & 399 & 207 & 192 & 0.090 \\
\hline \multicolumn{5}{|c|}{ Neoplasm histologic type } \\
\hline Classical/usual & 354 & 161 & 193 & \\
\hline Follicular & 100 & 68 & 32 & 6.97E-05 \\
\hline Tall cell & 35 & 16 & 19 & 0.990 \\
\hline \multicolumn{5}{|l|}{ Tumor stage } \\
\hline $\mathrm{T} 1$ & 141 & 71 & 70 & \\
\hline $\mathrm{T} 2$ & 164 & 86 & 78 & 0.717 \\
\hline $\mathrm{T} 3$ & 167 & 79 & 88 & 0.594 \\
\hline $\mathrm{T} 4$ & 22 & 10 & 12 & 0.669 \\
\hline \multicolumn{5}{|l|}{ Metastasis stage } \\
\hline M0 & 276 & 136 & 140 & \\
\hline M1 & 9 & 5 & 4 & 0.711 \\
\hline \multicolumn{5}{|l|}{ Lymph node stage } \\
\hline N0 & 224 & 122 & 102 & \\
\hline N1 & 222 & 94 & 128 & 0.010 \\
\hline
\end{tabular}

synthesized siRNA against ANO5 (siANO5) and transfected FTC-133 cells which have higher ANO5 expression. Real-time PCR and western blot results indicate that siRNA significantly decreased ANO5 expression (Fig. 3A and B). Cell migration assay showed that knockdown of $A N O 5$ increased the migrated cell number (Fig. 3C). Meanwhile, inhibition of ANO5 also promoted FTC-133 cell invasion (Fig. 3D). Our results prove that knockdown of ANO5 promotes FTC-133 cell migration and invasion.

Overexpression of ANO5 inhibits FTC-133 and TPC-1 cell migration and invasion. Next we detect the effect of ANO5 overexpression on thyroid cancer cell migration and invasion. Lentivirus expressing ANO5 was constructed and TPC-1 and FTC-133 cells infected. Real-time PCR and western blotting proved that ANO5 successfully expressed in TPC-1 and FTC-133 cells (Fig. 4A and B). Cell migration and invasion assays showed that ectopic expression of ANO5 decreased the invasive and migrated cell number of TPC-1 and FTC-133 cells (Fig. 4C and D). Collectively these data demonstrate that
Table III. The correlation of ANO5 expression with clinical characteristics of PTC.

\begin{tabular}{|c|c|c|c|c|c|}
\hline \multirow[b]{2}{*}{ Clinical characteristic } & \multirow{2}{*}{$\begin{array}{l}\text { No. of } \\
\text { patients }\end{array}$} & \multicolumn{2}{|c|}{$\begin{array}{c}\text { ANO5 } \\
\text { expression } \\
\text { (ct) }\end{array}$} & \multirow[b]{2}{*}{ p-value } & \multirow[b]{2}{*}{$\chi^{2}$} \\
\hline & & $>30$ & $\leq 30$ & & \\
\hline \multicolumn{6}{|l|}{ Age (years) } \\
\hline$<45$ & 32 & 17 & 15 & 0.3244 & 0.971 \\
\hline$\geq 45$ & 50 & 21 & 29 & & \\
\hline \multicolumn{6}{|l|}{ Gender } \\
\hline Male & 25 & 14 & 11 & 0.2456 & 1.349 \\
\hline Female & 57 & 26 & 33 & & \\
\hline \multicolumn{6}{|l|}{ Microcarcinoma } \\
\hline Yes & 33 & 16 & 17 & 0.6846 & 0.165 \\
\hline No & 49 & 26 & 23 & & \\
\hline \multicolumn{6}{|l|}{ Hashimoto's thyroiditis } \\
\hline Yes & 43 & 20 & 23 & 0.8415 & 0.04 \\
\hline No & 39 & 19 & 20 & & \\
\hline \multicolumn{6}{|l|}{ Multifocal } \\
\hline Yes & 29 & 13 & 16 & 0.2356 & 1.407 \\
\hline No & 53 & 31 & 22 & & \\
\hline \multicolumn{6}{|l|}{ LN metastasis } \\
\hline Yes & 32 & 22 & 10 & 0.0038 & 8.376 \\
\hline No & 50 & 18 & 32 & & \\
\hline
\end{tabular}

$\mathrm{T}$ indicates papillary thyroid cancer tissues. $\mathrm{Ct}=30$ is the average of cancer tissues.

overexpression of ANO5 inhibits FTC-133 and TPC-1 cell migration and invasion.

ANO5 activates the JAK/STAT3 pathway in thyroid cancer. To explore the mechanism by which $A N O 5$ regulates thyroid cancer cells migration and invasion, we carried out GSEA using public datasets (GSE3678). We found that lower ANO5 expression was negatively associated with some important signaling pathways such as TPO, KRAS, p53 and $V E G F$ (Fig. 5A). In addition, the results also showed that lower ANO5 expression was positively associated with JAK/STAT3 pathway which is well-known to be activated during cancer metastasis $(19,20)$ (Fig. 5B). Western blot results indicated that overexpression of $A N O 5$ suppressed phosphorylation of STAT3 but silencing of ANO5 increased the phosphorylation of STAT3 (Fig. 5C). Collectively these data demonstrated that ANO5 can regulate $J A K / S T A T 3$ signaling pathway in thyroid cancer.

\section{Discussion}

Most of thyroid cancers are well differentiated and have good prognosis, but lymph node metastasis usually increase the risk of recurrence and mortality (3-5). In this study, for the first time, we identified that ANO5 gene was documented to be expressed in 7 papillary thyroid carcinoma samples. 

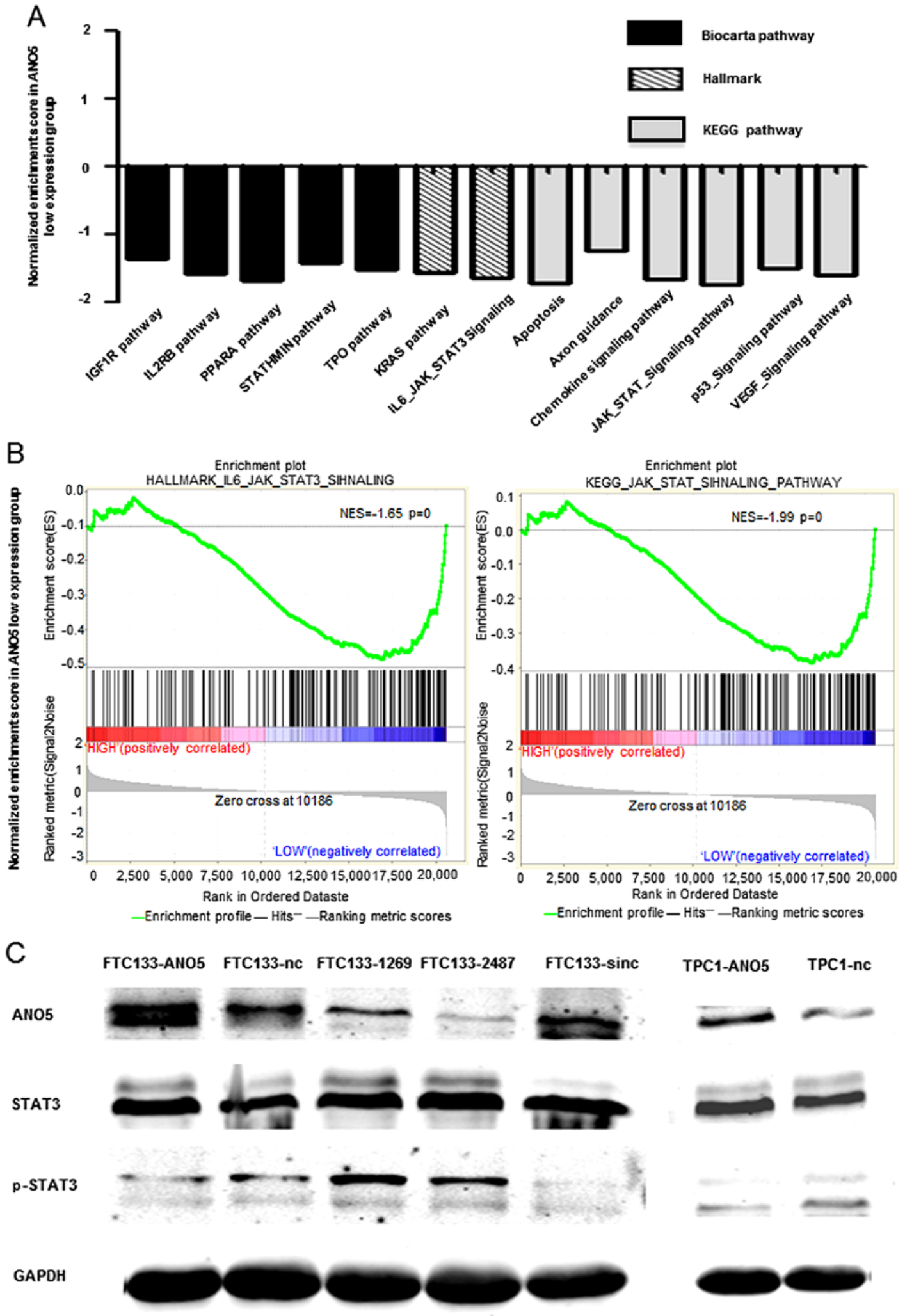

Figure 5. Anoctamin5 (ANO5) activates the JAK/STAT3 pathway in thyroid cancer. The metastasis pathway was activated in thyroid cancer patients having lower ANO5 expression. (A) Public dataset (GSE3678) was the lower ANO5 expression group, and the normalized enrichment score of three gene set categories was calculated by gene set enrichment analysis (GSEA). Each column represented one statistically significant gene set ( $<<0.05$ ). (B) GSEA was performed in thyroid cancer tissues with lower ANO5 expression versus higher ANO5 expression based on the gene sets of the JAK/STAT3 pathway. Two gene sets including metastasis and negative regulation of metastasis were activated in thyroid cancer patients with lower ANO5 expression, NES represents normalized enrichment score. (C) Western blotting was used to detect the effect of ANO5 on JAK/STAT3 signaling pathway. Overexpression of ANO5 can inhibit the phosphorylation of STAT3, while ANO5 knockdown activates the phosphorylation of STAT3.

Moreover, TCGA databases showed that expression of ANO5 in PTC with LN metastases $(\mathrm{n}=166)$ is lower than those without $\mathrm{LN}$ metastases (n=185) (Fig. 2B). We found ANO5 is downregulated in thyroid cancer tissues including PTC and 
FTC (Fig. 1E), downregulation of ANO5 promotes thyroid cancer cell migration and invasion (Fig. 3C and D), while overexpression of ANO5 has the opposite effect (Fig. 4C and D). Identifying the molecular events that regulate thyroid cancer metastasis holds promise for developing more effective prevention for human thyroid cancer. One of the major signaling pathways that is aberrantly activated and is critical for thyroid tumor metastasis is the JAK/STAT3 pathway by GSEA (Fig. 5B). The phosphorylated STAT3 protein can translocate into the nucleus, where it activates the transcription of various genes that regulate vital cellular functions, including cell proliferation and metastasis (26). These data suggested a relationship between ANO5 and JAK/STAT3 pathway activation, but it remained to be determined if the $J A K / S T A T 3$ pathway is required for thyroid cancer metastasis. These data indicated that ANO5 is a potential tumor suppressor gene in thyroid cancer, and downregulation of ANO5 participates in lymph node metastasis. Thus, the functional effect of ANO5 in PTC metastasis and has potential clinical value for developing gene therapy to treat PTC and subsequent lymph node or distant metastases and improving prognosis.

Other than $A N O 5$, some $A N O$ family members such as ANO1-4 and ANO6-10 have been reported to be related to tumors. Previous studies reported that ANOI, another member of anoctamin family, is upregulated in gastrointestinal stromal tumors (27) and head and neck squamous cell carcinomas (28), inhibition of ANOI can suppresses tumor invasion (29-32). We measured ANO5 expression in PTCs using a public database, and found that in contrast to $A N O 1$ expression, $A N O 5$ is downregulated in cancer tissues (Fig. 1C). Additional study of ANO5 revealed that it negatively regulate lymph node metastases of PTC, a role opposing that of $A N O 1$ in other tumors $(33,34)$. It has been reported that overexpression of ANO6 also increase cancer cell migration (12). ANO7 has been reported to participate in the development of breast (35) and prostate (36) cancers, the monoantiboby targeting the extracellular regions of ANO7 has a potential application for immunotherapy (37). ANO5 itself functions as a $\mathrm{Cl}^{-}$channel, but its activation requires higher $\mathrm{Ca}^{2+}$ concentration than other ANO members (38). Thus, some antagonism may exist among different ANO family members with respect to tumors, and this warrants further study.

In conclusion, we identified that $A N O 5$ is downregulated in thyroid cancer and downregulation of ANO5 promotes thyroid cancer cell migration and invasion. In addition, we found that the expression level of $A N O 5$ was correlated with activation of $J A K / S T A T 3$ pathway in thyroid cancer, suggesting a potential application of ANO5 as a biomarker. Altogether, our results demonstrate that targeting JAK/STAT3 pathway, using siRNA knockdown of ANO5, effectively promote lymph node metastasis of thyroid cancer, therefore, could be a potential novel therapeutic approach for treating lymph thyroid cancer. Thus, we confirmed that ANO5 is a novel potential biomarker of thyroid cancer and its expression correlates with lymph node metastasis. To further uncover the effect of ANO5 on proliferation and cell cycle and the detailed molecular mechanism of lymph node metastasis of thyroid cancer is necessary for clinical gene therapy in the future.

\section{Acknowledgements}

We would like to thank Lei Ye (Rui Jin Hospital) for providing us with TPC-1 and FTC-133 cells. This study was supported by the grants from the National Natural Science Foundation of China (grant nos. 81472501 and 81502197).

\section{References}

1. Sherman SI: Thyroid carcinoma. Lancet 361: 501-511, 2003.

2. Gilliland FD, Hunt WC, Morris DM and Key CR: Prognostic factors for thyroid carcinoma. A population-based study of 15,698 cases from the Surveillance, Epidemiology and End Results (SEER) program 1973-1991. Cancer 79: 564-573, 1997.

3. Podnos YD, Smith D, Wagman LD and Ellenhorn JD: The implication of lymph node metastasis on survival in patients with well-differentiated thyroid cancer. Am Surg 71: 731-734, 2005.

4. Lundgren Cl, Hall P, Dickman PW and Zedenius J: Clinically significant prognostic factors for differentiated thyroid carcinoma: A population-based, nested case-control study. Cancer 106: 524-531, 2006.

5. Wada N, Suganuma N, Nakayama H, Masudo K, Rino Y, Masuda $M$ and Imada T: Microscopic regional lymph node status in papillary thyroid carcinoma with and without lymphadenopathy and its relation to outcomes. Langenbecks Arch Surg 392: 417-422, 2007.

6. Myers JN, Greenberg JS, Mo V and Roberts D: Extracapsular spread. A significant predictor of treatment failure in patients with squamous cell carcinoma of the tongue. Cancer 92: 3030-3036, 2001

7. Allen CT, Law JH, Dunn GP and Uppaluri R: Emerging insights into head and neck cancer metastasis. Head Neck 35: 1669-1678, 2013.

8. Tian Y, Schreiber R and Kunzelmann K: Anoctamins are a family of $\mathrm{Ca}^{2+}$-activated $\mathrm{Cl}^{-}$channels. J Cell Sci 125: 4991-4998, 2012 .

9. Hartzell HC, Yu K, Xiao Q, Chien LT and Qu Z: Anoctamin/ TMEM16 family members are $\mathrm{Ca}^{2+}$-activated $\mathrm{Cl}^{-}$channels. J Physiol 587: 2127-2139, 2009.

10. Galindo BE and Vacquier VD: Phylogeny of the TMEM16 protein family: Some members are overexpressed in cancer. Int $J$ Mol Med 16: 919-924, 2005.

11. Liu F, Cao QH, Lu DJ, Luo B, Lu XF, Luo RC and Wang XG: TMEM16A overexpression contributes to tumor invasion and poor prognosis of human gastric cancer through TGF- $\beta$ signaling. Oncotarget 6: 11585-11599, 2015.

12. Jacobsen KS, Zeeberg K, Sauter DR, Poulsen KA, Hoffmann EK and Schwab A: The role of TMEM16A (ANO1) and TMEM16F (ANO6) in cell migration. Pflugers Arch 465: 1753-1762, 2013.

13. Bolduc V, Marlow G, Boycott KM, Saleki K, Inoue H, Kroon J, Itakura M, Robitaille Y, Parent L, Baas F, et al: Recessive mutations in the putative calcium-activated chloride channel Anoctamin 5 cause proximal LGMD2L and distal MMD3 muscular dystrophies. Am J Hum Genet 86: 213-221, 2010.

14. Penttilä S1, Palmio J, Suominen T, Raheem O, Evilä A, Muelas Gomez N, Tasca G, Waddell LB, Clarke NF, Barboi A, et al: Eight new mutations and the expanding phenotype variability in muscular dystrophy caused by ANO5. Neurology 78: 897-903, 2012.

15. Magri F, Del Bo R, D'Angelo MG, Sciacco M, Gandossini S, Govoni A, Napoli L, Ciscato P, Fortunato F, Brighina E, et al: Frequency and characterisation of anoctamin 5 mutations in a cohort of Italian limb-girdle muscular dystrophy patients. Neuromuscul Disord 22: 934-943, 2012.

16. Wahbi K, Béhin A, Bécane HM, Leturcq F, Cossée M, Laforêt P, Stojkovic T, Carlier P, Toussaint M, Gaxotte V, et al: Dilated cardiomyopathy in patients with mutations in anoctamin 5 . Int $\mathrm{J}$ Cardiol 168: 76-79, 2013.

17. Marconi C, Brunamonti Binello P, Badiali G, Caci E, Cusano R, Garibaldi J, Pippucci T, Merlini A, Marchetti C, Rhoden KJ, et al: A novel missense mutation in ANO5/TMEM16E is causative for gnathodiaphyseal dyplasia in a large Italian pedigree. Eur J Hum Genet 21: 613-619, 2013.

18. Lahoria R, Winder TL, Lui J, Al-Owain MA and Milone M: Novel ANO5 homozygous microdeletion causing myalgia and unprovoked rhabdomyolysis in an Arabic man. Muscle Nerve 50: 610-613, 2014. 
19. Wen W, Liang W, Wu J, Kowolik CM, Buettner R, Scuto A, Hsieh MY, Hong H, Brown CE, Forman SJ, et al: Targeting JAK1/STAT3 signaling suppresses tumor progression and metastasis in a peritoneal model of human ovarian cancer. Mol Cancer Ther 13: 3037-3048, 2014.

20. Yadav A, Kumar B, Datta J, Teknos TN and Kumar P: IL-6 promotes head and neck tumor metastasis by inducing epithelialmesenchymal transition via the JAK-STAT3-SNAIL signaling pathway. Mol Cancer Res 9: 1658-1667, 2011

21. Subramanian A, Tamayo P, Mootha VK, Mukherjee S, Ebert BL, Gillette MA, Paulovich A, Pomeroy SL, Golub TR, Lander ES, et al: Gene set enrichment analysis: A knowledge-based approach for interpreting genome-wide expression profiles. Proc Natl Acad Sci USA 102: 15545-15550, 2005.

22. Wu BH, Chen H, Cai CM, Fang JZ, Wu CC, Huang LY, Wang L and Han ZG: Epigenetic silencing of JMJD5 promotes the proliferation of hepatocellular carcinoma cells by downregulating the transcription of CDKN1A 686. Oncotarget 7: 6847-6863, 2016.

23. Cho YA, Kong SY, Shin A, Lee J, Lee EK, Lee YJ and Kim J: Biomarkers of thyroid function and autoimmunity for predicting high-risk groups of thyroid cancer: A nested case-control study. BMC Cancer 14: 873-883, 2014.

24. Liang H, Liu M, Yan X, Zhou Y, Wang W, Wang X, Fu Z, Wang N, Zhang S, Wang Y, et al: miR-193a-3p functions as a tumor suppressor in lung cancer by downregulating ERBB4. J Biol Chem 290: 926-940, 2015.

25. Kim HS, Kim DH, Kim JY, Jeoung NH, Lee IK, Bong JG and Jung ED: Microarray analysis of papillary thyroid cancers in Korean. Korean J Intern Med 25: 399-407, 2010.

26. Yu H, Pardoll D and Jove R: STATs in cancer inflammation and immunity: A leading role for STAT3. Nat Rev Cancer 9: 798-809, 2009.

27. West RB, Corless CL, Chen X, Rubin BP, Subramanian S, Montgomery K, Zhu S, Ball CA, Nielsen TO, Patel R, et al: The novel marker, DOG1, is expressed ubiquitously in gastrointestinal stromal tumors irrespective of KIT or PDGFRA mutation status. Am J Pathol 165: 107-113, 2004.

28. Carles A, Millon R, Cromer A, Ganguli G, Lemaire F, Young J, Wasylyk C, Muller D, Schultz I, Rabouel Y, et al: Head and neck squamous cell carcinoma transcriptome analysis by comprehensive validated differential display. Oncogene 25: 1821-1831, 2006.
29. Liu W, Lu M, Liu B, Huang Y and Wang K: Inhibition of Ca(2+)activated $\mathrm{Cl}(-)$ channel ANO1/TMEM16A expression suppresses tumor growth and invasiveness in human prostate carcinoma. Cancer Lett 326: 41-51, 2012.

30. Jia L, Liu W, Guan L, Lu M and Wang K: Inhibition of calciumactivated chloride channel ANO1/TMEM16A suppresses tumor growth and invasion in human lung cancer. PLoS One 10: e0136584, 2015.

31. Sui Y, Sun M, Wu F, Yang L, Di W, Zhang G, Zhong L, Ma Z, Zheng J, Fang X, et al: Inhibition of TMEM16A expression suppresses growth and invasion in human colorectal cancer cells. PLoS One 9: e115443, 2014.

32. Deng L, Yang J, Chen H, Ma B, Pan K, Su C, Xu F and Zhang J: Knockdown of TMEM16A suppressed MAPK and inhibited cell proliferation and migration in hepatocellular carcinoma. Onco Targets Ther 9: 325-333, 2016.

33. Shiwarski DJ, Shao C, Bill A, Kim J, Xiao D, Bertrand CA, Seethala RS, Sano D, Myers JN, Ha P, et al: To 'grow' or 'go': TMEM16A expression as a switch between tumor growth and metastasis in SCCHN. Clin Cancer Res 20: 4673-4688, 2014.

34. Sauter DRP, Novak I, Pedersen SF, Larsen EH and Hoffmann EK: ANO1 (TMEM16A) in pancreatic ductal adenocarcinoma (PDAC). Pflugers Arch 467: 1495-1508, 2015.

35. Li Y, Wang X, Vural S, Mishra NK, Cowan KH and Guda C: Exome analysis reveals differentially mutated gene signatures of stage, grade and subtype in breast cancers. PLoS One 10: $\mathrm{e} 0119383,2015$.

36. Mohsenzadegan M, Shekarabi M, Madjd Z, Asgari M, Abolhasani M, Tajik N and Farajollahi MM: Study of NGEP expression pattern in cancerous tissues provides novel insights into prognostic marker in prostate cancer. Biomarkers Med 9: 391-401, 2015.

37. Das S, Hahn Y, Walker DA, Nagata S, Willingham MC, Peehl DM, Bera TK, Lee B and Pastan I: Topology of NGEP, a prostate-specific cell:cell junction protein widely expressed in many cancers of different grade level. Cancer Res 68: 6306-6312, 2008.

38. Duran C, Qu Z, Osunkoya AO, Cui Y and Hartzell HC: ANOs 3-7 in the anoctamin/Tmem16 $\mathrm{Cl}^{-}$channel family are intracellular proteins. Am J Physiol Cell Physiol 302: C482-C493, 2012. 